\title{
PENDIDIKAN AKHLAK MENURUT IBN MISKAWAIH DAN RELEVANSINYA TERHADAP PENDIDIKAN KARAKTER BANGSA
}

\author{
Semin \\ Sekolah Tinggi Agama Islam (STAI) Madiun \\ mwahyu1504@gmail.com
}

\section{Abstrak}

The extraordinary development and explosion of science and information technology should also be accompanied by attention to education, especially moral education so that character education has lately been echoed as forming emotional intelligence of individuals, especially in the world of education being able to become a shield to be able to survive in the face of challenges of the times. Along with these problems Ibn Miskawaih in the book "Tahdzib Al Akblaq Wa tathhir al A'raq" defines the value of moral education with a mental state that is able to encourage someone to do an act spontaneously, without the need for consideration and thought. The state of the soul (morals) is divided into two categories, namely: Innate from birth (heredity / naturalyah), and morality that is produced through the process of training and habituation. While character education has a goal to straighten out various negative child behaviors into positive ones. The alignment process which is interpreted as a behavior correction is understood as a pedagogical process, then accompanied by an exemplary school and home environment, and a habituation process. Therefore the relevance of the concept of Ibn Miskawaih Moral Education with Nation Character Education includes: 1. The objectives contained in the moral education according to Ibn Miskawaih and the goals contained in Nation Character Education are the formation of noble morals. 2. The methods and materials used by Ibn Miskawaih in the 
concept of moral education are also in accordance with those contained in Nation Character Education. This is the point of relevance between the two concepts, namely the objectives, methods, and curriculum.

Kata Kunci: Pendidikan Akhlak, Pendidikan karakter Bangsa, Kitab Tahdzib Al Akhlaq Wa tathhir al-A'raq.

\section{A. PENDAHULUAN}

Pemahaman bahwa para remaja berkembang secara integral, dalam arti fungsi-fungsi jiwanya saling mempengaruhi secara organik. Karenanya sepanjang perkembangannya membutuhkan bimbingan yang terbaik dari orang yang lebih dewasa dan bertanggung jawab terhadap jiwa para remaja yang menurut kodratnya terbuka terhadap pengaruh dari luar.

Namun tidak jarang para remaja mengambil jalan pintas untuk mengatasi kemelut batin yang mereka alami itu. Pelarian batin ini terkadang akan mengarah ke perbuatan negatif dan merusak, seperti kasus narkoba, tawuran antar pelajar, maupun tindak kriminal merupakan bagian dari kegagalan para remaja dalam menemukan jalan hidup yang dapat menentramkan gejolak batinnya. Sehingga jika tingkah laku yang diperlihatkan sesuai dengan norma yang berlaku, maka tingkah laku tersebut dinilai baik dan diterima. Sebaliknya, jika tingkah laku tersebut tidak sesuai atau bertentangan dengan norma yang berlaku, maka tingkah laku dinilai buruk dan ditolak. ${ }^{1}$

Mengamati dengan seksama faktor yang menyebabkan dunia pendidikan menjadi sangat merosot adalah terabaikannya aspek moral. Konsentrasi pendidikan lebih banyak berorientasi kepada materi, sedangkan aspek ruhani dan moral sangat jarang diperhatikan. Kalaupun ada perhatian terhadap kedua aspek tersebut maka baru dalam tahap kognitif yang tidak dapat menyentuh nurani. Seiring dengan kemajuan zaman, rupanya pendidikan akhlak menjadi salah satu problem di masyarakat. Setiap hari, baik televisi maupun surat kabar menyuguhkan berbagai berita tentang maraknya tindakan amoral. ${ }^{2}$

${ }^{1}$ Jalaluddin, Psikologi Agama, edisi revisi 2005, (Jakarta: PT.Raja Grafindo Persada, 2005), 267.

2 Berdasarkan hasil penelitian yang dilakukan di kota-kota di Indonesia, sebanyak 42,5\% responden di Kupang NTT telah melakukan seks bebas, sedangkan 17\% responden di Palembang, Sumatra Selatan, Tasikmalaya dan Jawa Barat melakukan hal yang sama. Bahkan di kota-kota besar, kasus-kasus tersebut memiliki grafik yang sangat tinggi. Seperti Medan, Jakarta, Bandung, Surabaya melebihi angka 50\%. Yang lebih mengejutkan di Yogyakarta, sebanyak 97,05\% remajanya telah melakukan seks bebas. Lihat, Jamal Ma’mur Asmani, Buku 
Pesta narkoba, tawuran siswa antar sekolah, korupsi, bentrokan massa bahkan pembunuhan.

Mencuatnya problem-problem ini ditengarai karena banyak faktor, seperti pengaruh negatif globalisasi. ${ }^{3}$ Ironis memang, dalam konteks masyarakat modern saat ini, agaknya penanaman nilai pendidikan akhlak kurang begitu dipedulikan. Masyarakat cenderung terlena dengan kehidupan hedonisme. ${ }^{4}$

Untuk mengatasi dekadensi moral yang telah merebak di masyarakat, perlu adanya solusi. Pendidikan akhlak menjadi salah satu alternatif jawabannya. Karena sebaik apapun seseorang jika tak memiliki akhlak yang baik maka tidak akan bernilai baik. Sebaliknya, jika memiliki akhlak yang baik maka orang tersebut akan menjadi berharga dan bernilai baik dimata insan yang lain maupun dihadapan Allah SWT. Akhlak yang indah yang dimaksudkanya adalah ilmu, akal pemeliharaan diri dari hal-hal yang tidak baik bagi dirinya (iffah), keberanian, taqwa, kemurahan hati, kepribadian dan sifat-sifat kebaikan yang lain. ${ }^{5}$ Karena pada dasarnya, pendidikan akhlak berusaha untuk meluruskan naluri dan kecenderungan fitrah seseorang yang membahayakan masyarakat, dan membentuk rasa kasih sayang mendalam yang akan menjadikan seseorang merasa terikat untuk melakukan amal baik dan menjauhi amal jelek. ${ }^{6}$

Rupanya pendidikan akhlak ini sejalan dengan program pemerintah Indonesia. Sejak tahun 2010, pemerintah melalui Kementerian Pendidikan Nasional mencanangkan penerapan pendidikan karakter bagi semua tingkatan pendidikan, baik sekolah dasar hingga perguruan tinggi.?

Panduan Internalisasi Pendidikan Karakter di Sekolah (Yogyakarta: Diva Press, 2011), 28.

3 Dampak negatif globalisasi seperti: lahirnya generasi instan (langsung bisa menikmati keinginan tanpa proses perjuangan dan kerja keras, dekadensi moral dan konsumerisme, bahkan permisifisme. Ibid., 7 .

4 Secara sederhana, hedonisme merupakan sebuah doktrin yang mengatakan bahwa kebaikan yang pokok dalam kehidupan adalah kenikmatan. Lihat, Ahmad Maulana et. al., Kamus Ilmiah Populer (Yogyakarta: Absolut, 2008), 191. Kata "Hedonis" sendiri berasal dari bahasa Yunani hedone yang berarti "kesenangan" atau "kenikmatan". Dalam filsafat Yunani, Hedonisme ini ditemukan oleh Aristippos dari Kyrene (sekitar 433-355 SM), yang merupakan murid Socrates. Socrates bertanya tentang tujuan terakhir bagi kehidupan manusia, tetapi ia tidak memberikan jawaban yang jelas. Kemudian Aristippos menjawab,"Yang sungguh-sungguh baik bagi manusia adalah kesenangan.....

5 Imam al-Ghozali, Ihya' 'Ulumiddin (Semarang: Cv.Asy Syifa',1994), 520.

6 Basuki dan Miftahul Ulum, Pengantar Ilmu Pendidikan Islam (Ponorogo: Stain Po Press, 2007), 40-41.

7 Nurla Isna Aunillah, Panduan Menerapkan Pendidikan Karakter di Sekolah (Jakarta: Laksana, 
Pendidikan karakter adalah sebuah sistem yang menanamkan nilai-nilai karakter pada peserta didik, yang mengandung komponen pengetahuan, kesadaran individu, tekad, serta adanya kemauan dan tindakan untuk melaksanakan nilai-nilai, baik terhadap Tuhan Yang Maha Esa, diri sendiri, sesama manusia, lingkungan maupun bangsa, sehingga akan terwujud insãn kãmil. ${ }^{8}$

\section{B. PEMBAHASAN}

\section{Pendidikan Akhlak}

Akhlak adalah sesuatu kekuatan dalam kehendak dan kehendak berkombinasi membawa kecenderungan pada pemilihan pihak yang benar (dalam hal akhlak yang baik) atau pihak yang jahat (dalam hal akhlak yang jahat). ${ }^{9}$ kata "akhlaq" berasal dari bahasa arab, yaitu jamak dari "khuluqun" yang secara linguistik diartikan dengan budi pekerti, perangai, tingkah laku atau tabiat, tata krama, sopan santun, adab dan tindakan. ${ }^{10}$ Dalam kamus besar bahasa Indonesia kata akhlak diartikan sebagai budi pekerti atau kelakuan. ${ }^{11}$ Secara terminologi pengertian akhlak adalah sebuah tatanan yang tertanam kuat dalam jiwa yang darinya muncul beragam perbuatan dengan mudah dan ringan, tanpa membutuhkan pemikiran dan pertimbangan. ${ }^{12}$

2011), 9.

8 Ibid., 18-19. Penjelasan "insan kamil" disebutkan dalam beberapa sumber, di antaranya adalah manusia yang dalam hidupnya senantiasa beramal shalih (berbuat baik), yang didasari dengan iman kepada Allah, dan merealisasikan dalam sikap takwa. Lihat, Amin Syukur, Tasawuf Bagi Orang Awam Menjawab Problem Kehidupan (Yogyakarta: Pustaka Pijar, 2006), 152. Sedangkan pengertian "insan kamil" menurut Muhammad Alim, terfokus pada pengembangan potensi jasmani dan rohani yang sehat, yakni manusia yang sehat dan terbina potensi rohaniyahnya, sehingga dapat berfungsi secara optimal dan dapat berhubungan dengan Allah dan makhluk lainnya secara benar. Ciri-cirinya antara lain: a) berfungsi akalnya secara optimal, b) ber-fungsi intuisinya secara optimal, c) mampu menciptakan budaya, d) menghiasai diri dengan sifat-sifat ketuhanan, e) berakhlak mulia, f) berjiwa seimbang. Lihat, Muhammad Alim, Pendidikan Agama Islam Upaya Pembentukan Pemikiran dan Kepribadian Muslim (Bandung: PT Remaja Rosdakarya, 2006), 160-162. Bandingkan juga, Murtadha Muthahhari, Manusia Sempurna Pandangan Islam Tentang Hakikat Manusia terj. Moh. Hashem (Jakarta: Lentera, 1994), 1-4.

9 Erwin Yudi Prahara, Materi Pendidikan Agama Islam. ( Ponorogo: STAIN Po Press), 2009, 182.

${ }^{10}$ Beni Ahmad Saebani, ilmu akblak. (Bandung: Pustaka Setia), 2010, 13.

${ }^{11}$ Heri Gunawan, Pendidikan Karakter Konsep Dan Implementasi, (Bandung: Alfabeta), 2012, 4.

${ }^{12}$ Ibrahim Bafadhol, Pendiidkan Akhlak Perspektif Islam, Edukasi Islami: Jurnal Pendidikan Islam, Vol. 6 No. 22017 dalam https://jurnal.staialhidayahbogor.ac.id/index.php/ei/article/ 


\section{Landasan Pendidikan Akhlak \\ a. Al-Qurian}

Al-Qur'an merupakan kitab suci yang diturunkan Allah SWT kepada Rasul dan Nabi-Nya yang terakhir Muhammad SAW melalui Malaikat Jibril untuk disampaikan kepada seluruh umat manusia sampai akhir zaman nanti. Oleh karena itu, Al-Qur'an sebagai manifestasi kalam Allah yang qadim (tidak diciptakan) dan bukanlah hasil pemikiran manusia.

Adapun sumber Al-Qur'an yang menjelaskan tentang pendidikan akidah akhlak, antara lain sebagai berikut:

- Al-Qur'an surat Al-Qalam ayat 4

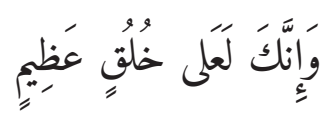

Artinya: dan Sesungguhnya kamu benar-benar berbudi pekerti yang agung. ${ }^{13}$

- Al-Qur'an surat An-Nahl ayat 90

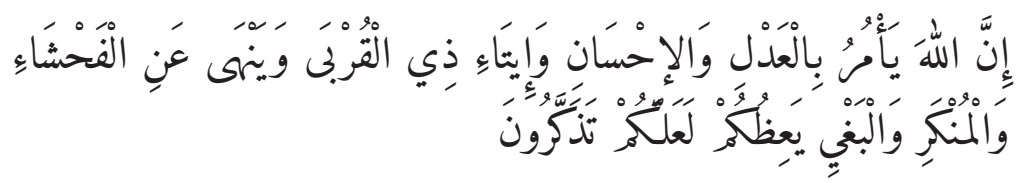

Artinya: Sesungguhnya Allah menyuruh (kamu) Berlaku adil dan berbuat kebajikan, memberi kepada kaum kerabat, dan Allah melarang dari perbuatan keji, kemungkaran dan permusuhan. Dia memberi pengajaran kepadamu agar kamu dapat mengambil pelajaran. ${ }^{14}$

Beberapa ayat di atas menjelaskan kepada manusia bahwa Allah sangat mencintai akhlak mulia dan sangat membenci akhlak tercela, seperti: baik dalam pergaulan, memuliakan orang lain, lemah lembut dalam tingkah laku, mengajak kepada kebaikan, memberikan makan, mengucapkan salam, toleransi, menahan amarah. Juga menjauhkan apa-apa yang diharamkan Allah, seperti: melakukan perbuatan batil, berbohong, pelit, sombong, akhlak tercela, dan melakukan kezaliman. Tidak ada satu perbuatan baik pun kecuali Rasulullah telah memerintahkan kita untuk mengerjakanya, dan tidak ada satu perbuatan jelek kecuali beliu melarangnya.

view/178 45-61

13 Al-Qur'an, 68:4.

${ }^{14}$ Ibid., 16: 90. 
Demikianlah Allah membina akhlak - akhlak hamba-hambaNya terutama Rasulullah SAW dalam akhlak-akhlak yang mulia.

\section{b. Al-Hadist}

Sedangkan Al-Hadist merupakan sesuatu yang disandarkan kepada Nabi Muhammad SAW yaitu berupa perkataan, perbuatan, pernyataan, dan sifatsifat atau keadaan-keadaan Nabi Muhammad yang lain. bisa disebut penjelasan atas Al-Qur'an. Ketika 'Aishah ditanya tentang akhlak Rasulullah, ia menjawab: $:^{15}$

\section{كان خلة القرأن}

“Akblak Rasulullah adalah al-Qur'an."(HR.Sa’ad bin Hisyam)

Rasulullah SAW telah mengajarkan metodologi membentuk moralitas yang mulia, terkait dengan akhlak manusia terhadap Allah, diri sendiri maupun kepada sesama makhluk. Beliau tak hanya memerintahkan disfungsi teori balaka, namun juga realitas konkrit suri teladan umatnya. Semua akhlak yang diajarkan Rasulullah tak lain adalah moralitas yang bermuara pada al-Qur'an. ${ }^{16}$ Dengan demikian, jelas bahwa Rasulullah Saw. memiliki tingkah laku yang mulia, beliau selalu bertindak sesuai dengan petunjuk yang berada dalam al-Qur'an.

Al-Qur'an menggambarkan akidah orang-orang beriman, kelakuan mereka yang mulia, dan gambaran hidup mereka yang tertib, adil, luhur dan mulia. Hal ini sangat berlawanan secara diametral dengan perwatakan orangorang kafir dan munafik yang jelek, zālim, dan sombong. Al-Qur'an juga menggambarkan perjuangan para rasul untuk menegakkan nilai-nilai mulia dan murni di dalam kehidupan dan ketika mereka ditentang oleh kefasikan, kekufuran dan kemunafikan yang menggagalkan tegaknya akhlak mulia sebagai pijakan dalam kehidupan. ${ }^{17}$

Adapun sumber Al-Hadist yang menjelaskan tentang pendidikan aqidah akhlak, antara lain sebagai berikut:

${ }^{15}$ Sa’id Hawwa, Tazkiyatun Nafs intisari Ibya Ulumuddin (Jakarta: Pena Budi Askara, 2005), 462.

${ }^{16}$ FKI LIM, Gerbang Pesantren, Pengantar Memahami Ajaran Ablussunnah wal Jama'ah (Kediri: Bidang Penelitian dan Pengembangan LIM PP Lirboyo, 2010), 7.

${ }_{17}$ Rosihan Anwar, Akblak Tasawuf, Akblak Tasawuf( Bandung: Pustaka Setia, 2010), 21 


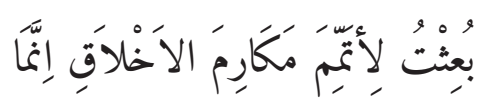

"Sesunggubnya aku diutus, hanya untuk memperbaiki akhlak manusia." (HR.Baihaqi). ${ }^{18}$

Dari hadist di atas dapat disimpulkan bahwa manusia dalam beribadah atau melakukan satu kebaikan lebih dititik beratkan pada keikhlasan yang ada dalam hati, sebab Allah hanya melihat dimana sumber perbuatan manusia tersebut. Maka dari itu kita wajib bertakwa kepada Allah SWT dimana saja berada dengan jalan berbuat baik kepada sesama manusia sehingga terhapuslah dosa-dosa yang pernah kita lakukan. Yang akhirnya terwujudlah akhlak yang sempurna, karena Allah menyukai seseorang yang berakhlak mulia dan luhur, sebaliknya Allah juga tidak menyukai seseorang yang berakhlak buruk. Untuk itu, sangat berat apabila seseorang melakukan perbuatan baik tanpa diimbangi dengan ketulusan yang apa adanya.

\section{Ruang Lingkup Pendidikan Akhlak}

Pendidikan akhlak meliputi persoalan-persoalan kebaikan, kesopanan, tingkah laku yang terpuji serta berbagai persoalan yang timbul dalam kehidupan sehari-hari dan bagaimana seseorang bertingkah laku. ${ }^{19}$ Ruang lingkup pendidikan akhlak, pada dasarnya tidak lepas dari akhlak terhadap Sang Khaliq dan akhlak terhadap makhluk. Namun untuk lebih jelasnya, akan dipaparkan klasifikasi tersebut dalam penjelasan di bawah ini:

\section{a. Akblak terhadap Allah SWT}

Akhlak terhadap Allah Swt, merupakan sikap atau perbuatan yang seharusnya dilakukan oleh manusia sebagai makhluk terhadap Khaliqnya. Diantara perbuatan yang termasuk dalam kategori ini adalah iman, ihsan, takwa, ikhlas, tawakal, ${ }^{20}$ husn al-z\}ann dan $z$ \} ikrullah. ${ }^{21}$

\footnotetext{
${ }^{18}$ Sa’id Hawwa, Tazkiyatun Nafs intisari Ihya Ulumuddin (Jakarta: Pena Budi Askara, 2005), 463.

${ }_{19}$ M. Abdul Qadir Ahmad, Metodologi Pengajaran Agama Islam (Jakarta: Rineka Cipta, 2008), 201.

${ }^{20}$ Muhammad Alim, Pendidikan Agama Islam Upaya Pembentukan Pemikiran dan Kepribadian Muslim (Bandung: Remaja Rosdakarya, 2006), 153-154.

${ }^{21}$ Anwar, Akblak Tasawuf, 91-92.
} 


\section{b. Akblak terhadap Rasulullab SAW}

Akhlak kepada Rasulullah SAW dapat ditunjukkan dengan mencintai Rasulullah secara tulus dengan mengikuti semua ajaran beliau. Diantaranya dapat ditunjukkan dengan sikap:

1). Mencintai dan memuliakan Rasulullah SAW.

Nabi Muhammad SAW telah berjuang selama lebih kurang 23 tahun membawa umat manusia keluar dari kegelapan menuju cahaya yang terang benderang. Beliaulah yang berjuang membebaskan umatnya dari keterpurukan. Hal ini menunjukkan Nabi sangat mencintai umatnya. Oleh karenanya, sebagai seorang mukmin sudah seharusnya mencintai beliau melebhi siapapun selain Allah. Setelah itu, umatnya juga berkewajiban menghormati dan memuliakan beliau. Seperti tidak boleh mendahului beliau dalam mengambil keputusan atau menjawab pertanyaan. ${ }^{22}$

2). Mengikuti dan mentaati Rasulullah SAW.

Sikap seperti ini merupakan salah satu bukti kecintaan seorang hamba terhadap Allah SWT. Apa saja yang datang dari Rasulullah harus diterima, apa yang diperintahkannya diikuti, dan apa yang dilarangnya ditinggalkan. Ketaatan terhadap Rasulullah SAW bersifat mutlak, karena taat kepada beliau merupakan bagian dari taat kepada Allah SWT.23

\section{c Akblak terhadap keluarga}

Akhlak dalam kategori ini meliputi akhlak kepada orang tua, anak, suami, istri, sanak saudara, kerabat yang berbeda agama, karib kerabat dan lain-lain. Hal ini dapat tercermin dengan sikap saling membina rasa cinta dan kasih sayang dalam kehidupan. Menurut Imam Al-Ghazali keluarga memegang peranan penting dalam pendidikan akhlak. ${ }^{24}$ Mengenai pendidikan akhlak terhadap orang tua/keluarga, Ibn Miskawaih banyak mengambil pemikiran Martin Plessner, terutama peranan orang tua terhadap anak sejak usia dini. Menurut para ahli psikologi pada masa ini disebut juga usia meniru, dimana anak-anak meniru pembicaraan dan tingkah laku orang lain. Dengan demi-

${ }^{22}$ Yunahar Ilyas, Kuliah Akblak. (Yogyakarta: Lembaga Pengkajian dan Pengamalan Islam), 2006. 65-66.

${ }^{23}$ Ibid., 70-71.

${ }^{24}$ Sholeh, Pendidikan Akhlak Dalam Lingkungan Keluarga Menurut Imam Ghazali, https:// journal.uir.ac.id/index.php/althariqah/article/view/618/320 
kian orang tua pada masa ini harus berhati-hati dalam bertindak dan berbicara, karena segala sesuatu yang dicontohkan pada masa anak usia dini akan melekat hingga anak dewasa. ${ }^{25}$ Orang tua harus menanamkan cinta kebajikan dan melatihnya untuk membiasakan kebajikan itu, sehingga ia akan membenci kejelekan/keburukan yang ada. Karena hal ini akan menjadi pegangan baginya untuk berakhlak mulia terhadap siapapun, terutama dimulai dari lingkup keluarga. ${ }^{26}$

\section{d. Akblak kepada lingkungan}

Lingkungan adalah segala sesuatu yang ada di sekitar manusia baik binatang, tumbuh-tumbuhan, dan benda tak bernyawa (abudin Nata) Allah menciptakan binatang, tumbuh-tumbuhan dan benda tak bernyawa yang semuanya memiliki ketergantungan kepada-Nya, keyakinan ini menghantarkan sesama muslim untuk menyadari bahwa semua makhluk Tuhan yang harus diperlakukan secara wajar dan baik. Pada dasarnya al-Qur'an terhadap lingkungan menurut Quraish Shihab bersumber dari fungsi manusia sebagai khalifah menuntut adanya interaksi antara manusia dengan sesamanya dan manusia terhadap alam. ${ }^{27}$

Dari keterangan tersebut dapat ditegaskan bahwa setiap manusia dituntut mampu menghormati proses-proses yang sedang berjalan dan terhadap semua proses yang terjadi. Yang demikian menghantarkan manusia bertanggungjawab sehingga ia tidak melakukan perusakan bahkan dengan kata lain setiap perusakan terhadap lingkungan harus dinilai sebagai perusakan pada diri sendiri. ${ }^{28}$

\section{e. Akblak kepada makhluk lain selain manusia}

Akhlak kepada bukan manusia (lingkungan hidup), seperti sadar memelihara lingkungan hidup, menjaga dan memanfaatkan alam, terutama hewani dan nabati, untuk kepentingan manusia dan makhluk lainya, sayang pada

\footnotetext{
${ }^{25}$ Herawati, Pendiidkan Akhlak Bagi Anak Usia Dini, Bunayya, Jurnal Pendidikan Anak, Vol. III No. 2 Juli - Desember 2017 https://jurnal.ar-raniry.ac.id/index.php/bunayya/article/ view/1703 124-136

${ }^{26}$ http://etd.eprints.ums.ac.id/4829/, diakses 16 Novemberr 2019.

${ }^{27}$ Heri Gunawan, Pendidikan Karakter Konsep dan Implementasi (Bandung: Alfabeta, 2012), 11.

${ }^{28}$ Ibid., 12.
} 
sesama makhluk dan menggali potensi alam seoptimal mungkin demi kemaslahatan manusia dan alam sekitar. ${ }^{29}$

\section{Pendidikan Karakter Bangsa \\ a. Pengertian Pendidikan Karakter}

Kata karakter berasal dari bahasa Yunani yang berarti to mark (menandai) dan memfokuskan pada bagaimana mengaplikasikan nilai kebaikan dalam bentuk tindakan atau tingkah laku. ${ }^{30}$ Pendidikan karakter, menurut Ratna Megawangi "sebuah usaha untuk mendidik anak-anak agar dapat mengambil keputusan dengan bijak dan mempratikanya dalam kehidupan sehari-hari sehingga mereka dapat memberikan kontribusi yang positif kepada lingkunganya. ${ }^{31}$ Selanjutnya menurut Suyanto, karakter adalah cara berfikir dan berprilaku yang menjadi ciri khas individu untuk hidup dan bekerja sama, baik dalam lingkup keluarga, masyarakat, bangsa dan negara. ${ }^{32}$ Sedangkan menurut Nopan Omeri karakter merupakan perpaduan antara moral, etika, dan akhlak. ${ }^{33}$ Berbeda dengan Hermawan Kertajaya yang menyatakan, bahwa karakter adalah ciri khas yang dimiliki oleh suatu benda atau individu. Ciri khas tersebut bersifat asli dan mengakar pada kepribadian benda atau individu tersebut, dan merupakan mesin yang mendorong bagaimana seseorang bertindak, bersikap, berujar dan merespon sesuatu. ${ }^{34}$ Dalam kaitannya dengan pendidikan nasional, pembentukan karakter menjadi salah satu tujuannya. Hal ini sesuai dengan UUSPN No.20 tahun 2003 Bab 2 pasal 3: Pendidikan nasional berfungsi mengembangkan kemampuan dan membentuk watak serta peradaban bangsa yang bermartabat dalam rangka menecerdaskan kehidupan bangsa, berkembangnya potensi peserta didik agar menjadi manusia

${ }^{29}$ Aminuddin, et al., Membangun Karakter dan Kepribadian Melalui Pendidikan Agama Islam, 99 .

${ }^{30}$ Tadkirotun Musfiroh, "Pengembangan Karakter Anak Melalui Pendidikan Karakter" dalam Tinjauan Berbagai Aspek Character Building: Bagaimana Mendidik Anak Berkarakter? (Yogyakarta: Tiara Wacana, 2008), 28.

${ }^{31}$ Darma kusuma, ea al.,Pendidikan Karakter, (Banndung: PT Remaja Rosdakarya, 2011),5.

${ }^{32}$ Agus Wibowo, Pendidikan Karakter Strategi Membangun Karakter Bangsa Berperadapan (Yogyakarta: Pustaka Pelajar, 2012), 33.

${ }^{33}$ Nopan Omeri, "Pentingnya Karakter Dalam Dunia Pendidikan." MAPEN: Jurnal Manajer Pendidikan 9, no. 3 (2015). https://ejournal.unib.ac.id/index.php/manajerpendidikan/ article/view/1145/0 464-468

${ }^{34}$ Jamal Ma'mur Asmani, Buku Panduan Internalisasi Pendidikan Karakter di Sekolah (Yogyakarta: Diva Press, 2011), 28. 
yang beriman dan bertakwa kepada Tuhan Yang Maha Esa, berakhlak mulia, berilmu, cakap, kreatif, mandiri, dan menjadi warga negara yang demokratis serta bertanggung jawab. ${ }^{35}$

Berdasarkan pada beberapa pengertian tersebut di atas, dapat dimaknai bahwa karakter adalah keadaan asli yang ada dalam diri individu seseorang yang membedakan antara dirinya dengan orang lain. Pengertian karakter, watak dan kepribadian memang sering tertukar-tukar dalam penggunaanya. Olek karena itu, tidak heran jika dalam penggunaanya seseorang terkadang tertukar menyebutkan karakter, watak atau kepribadianya. ${ }^{36}$ Seseorang dianggap berkarakter mulia, jika ia memiliki pengetahuan yang mendalam tentang potensi dirinya dan mampu merealisasikan potensi tersebut dalam sikap dan perbuatannya. ${ }^{37}$

\section{b. Nilai-nilai Dalam Pendidikan Karakter Bangsa}

Pendapat Djahiri yang mengatakan bahwa nilai adalah suatu jenis kepercayaan seseorang, tentang bagaimana seseorang sepatutnya, atau tidak sepatutnya dalam melakukan sesuatu, atau tentang apa yang berharga dan yang tidak berharga untuk dicapai. ${ }^{38}$ Selanjutnya Ari Ginajar Agustian yang terkenal dengan konsepnya "Emotional Spiritual Question (ESQ)" mengajukan pemikiranya, bahwa setiap karakter positif sesungguhnya akan merujuk pada sifat-sifat Allah yang terdapat dalam asma al-husna (nama-nama Allah yang baik) yang berjumlah 99. Asma al-husna ini harus menjadi sumber inspirasi perumusan karakter oleh siapapun, karena dala asma al-husna terkandung sifat-sifat Allah yang baik. ${ }^{39}$

Berbeda dengan yang diungkapkan oleh Lickona ${ }^{40}$, yang menekankan

${ }^{35}$ Darma kusuma, ea al.,Pendidikan Karakter, 6. Dan UU No. 20 Tahun 2003 tentang Sistem Pendidikan Nasional. Bandung: Umbara, 2003.

${ }^{36}$ Heri Gunawan, Pendidikan Karakter Konsep Dan Implementasi 3.

${ }_{37}$ Nurla Isna Aunillah, Panduan Menerapkan Pendidikan Karakter di Sekolah (Jakarta: Laksana, 2011), 20.

${ }^{38}$ Heri Gunawan, Pendidikan Karakte Konsep Dan Implementasi, 31.

${ }^{39}$ Heri Gunawan, Pendidikan Karakte Konsep Dan Implementasi, 32.

${ }^{40}$ Lickona bernama lengkap Thomas Lickona, merupakan salah satu tokoh pemikir pendidikan karakter kontemporer. Ia memiliki pandangan, bahwa terjadi dikotomi antara pendidikan karakter dan pendidikan agama. Keduanya seharusnya dipisahkan dan tidak dicampuradukkan. Baginya, nilai dasar harus dihayati jika masyarakat masih mau hidup dan bekerja secara damai. Nilai-nilai yang seharusnya diprioritaskan dalam pendidikan karakter adalah nilai kebijaksanaan, penghormatan terhadap yang lain, tanggung jawab pribadi, perasaan senasib sependeritaan (public compassion), pemecah konflik secara damai. Lebih 
tiga komponen karakter yang baik, yaitu moral knowing (pengetahuan tentang moral), moral feeling (perasaan tentang moral), dan moral action (perbuatan moral), sehingga dengan komponen tersebut, seseorang diharapkan mampu memahami, merasakan dan mengerjakan nilai-nilai kebajikan. ${ }^{41}$

Nilai-nilai dalam Pendidikan Budaya dan Karakter Bangsa Nilai-nilai yang dikembangkan dalam pendidikan budaya dan karakter bangsa diidentifikasi dari sumber-sumber berikut ini.

1) Agama masyarakat Indonesia adalah masyarakat beragama. Oleh karena itu, kehidupan individu, masyarakat, dan bangsa selalu didasari pada ajaran agama dan kepercayaannya. Secara politis, kehidupan kenegaraan pun didasari pada nilai-nilai yang berasal dari agama. Atas dasar pertimbangan itu, maka nilai-nilai pendidikan budaya dan karakter bangsa harus didasarkan pada nilai-nilai dan kaidah yang berasal dari agama.

2) Pancasila: negara kesatuan Republik Indonesia ditegakkan atas prinsip-prinsip kehidupan kebangsaan dan kenegaraan yang disebut Pancasila. Pancasila terdapat pada Pembukaan UUD 1945 dan dijabarkan lebih lanjut dalam pasal-pasal yang terdapat dalam UUD 1945.Artinya, nilai-nilai yang terkandung dalam Pancasila menjadi nilai-nilai yang mengatur kehidupan politik, hukum, ekonomi, kemasyarakatan, budaya, dan seni.

3) Pendidikan budaya dan karakter bangsa bertujuan mempersiapkan peserta didik menjadi warga negara yang lebih baik, yaitu warga negara yang memiliki kemampuan, kemauan, dan menerapkan nilainilai Pancasila dalam kehidupannya sebagai warga negara.

4) Budaya: sebagai suatu kebenaran bahwa tidak ada manusia yang hidup bermasyarakat yang tidak didasari oleh nilai-nilai budaya yang diakui masyarakat itu. Nilai-nilai budaya itu dijadikan dasar dalam pemberian makna terhadap suatu konsep dan arti dalam komunikasi antaranggota masyarakat itu. Posisi budaya yang demikian penting

lanjut, menurutnya agama bukan menjadi urusan sekolah negeri (public school). Sedangkan pendidikan karakter tidak ada relevansinya dengan ibadah dan doa-doa yang dilakukan dalam lingkungan sekolah. Agama memiliki hubungan vertikal antara sorang pribadi dengan keilahian, sedangkan pola pendidikan karakter adalah horisontal di dalam masyarakat, antara individu satu dengan yang lain. Lihat, Abdul Majid, Pendidikan Karakter Persfektif Islam (Bandung: Remaja Rosdakarya, 2011), 61-62.

${ }^{41}$ Masnur Muslih, Pendidikan Karakter Menjawab Tantangan Krisis Multidimensional. (Jakarta; Bumi Aksara, 2011), 75. 
dalam kehidupan masyarakat mengharuskan budaya menjadi sumber nilai dalam pendidikan budaya dan karakter bangsa.

5) Tujuan Pendidikan Nasional: sebagai rumusan kualitas yang harus dimiliki setiap warga negara Indonesia, dikembangkan oleh berbagai satuan pendidikan di berbagai jenjang dan jalur. Tujuan pendidikan nasional memuat berbagai nilai kemanusiaan yang harus dimiliki warga negara Indonesia. Oleh karena itu, tujuan pendidikan nasional adalah sumber yang paling operasional dalam pengembangan pendidikan budaya dan karakter bangsa.

\section{c. Metode Pendidikan Karakter Bangsa}

Secara umum istilah strategi sering dimaknai, sebagai garis besar haluan untuk bertindak dalam usaha yang telah ditentukan.

Sebagaimana yang di kutip Heri Gunawan, J.R. David mengatakan, dalam dunia pendidikan strategi diartikan sebagai, a plan method, or series of activities designed to achieves particular educational goal. Dalam pandangan David, strategi dalam pendidikan dapat diartikan sebagai perencanaan yang berisi tentang rangkaian kegiatan yang di desain untuk mencapai tujuan pendidikan tertentu. Dari pengertian yang dikatakan David di atas, ada dua hal yang perlu dicermati. ${ }^{42}$ Pertama, strategi pembelajaran merupakan rencana tindakan (rangkaian kegiatan) termasuk penggunaan metode dan pemanfaatan sumberdaya dalam proses pembelajaran. Kedua, strategi disusun untuk mencapai kegiatan tertentu. Artinya arah dari semua keputusan penyusunan strategi adalah pencapaian tujuan. ${ }^{43}$ Termasuk dalam pendidikan karakter diperlukan metode-metode pendidikan yang mampu menanamkan nila-nilai karakter baik kepada siswa, sehingga siswa bukan hanya tahu tentang moral (karakter) atau moral knowing. Berkaitan dengan hal ini, metode pendidikan yang diajukan oleh Abdurrahman An-Nahlawi dapat menjadi pertimbangan para pendidik dalam menginternalisasikan pendidikan karakter kepada semua pesrta didik. Metode-metode yang ditawarkan an-Nahlawi tersebut adalah sebagai berikut: ${ }^{44}$

1) Metode hiwar atau percakapan: metode hiwar (dialog) ialah percakapan silih berganti antara pihak satu atau lebih melalui tanya jawab mengenai satu topik, dan dengan sengaja diarahkan kepada satu

\footnotetext{
${ }^{42}$ Heri Gunawan, Pendidikan Karakter Konsep Dan Implementasi, 184.

${ }^{43}$ Ibid., 185.

${ }^{44}$ Heri Gunawan, Pendidikan Karakter Konsep Dan Implementasi, 88.
} 
tujuan yang dikehendaki.

2) Metode qishah atau cerita: mengandung arti potongan berita yang diikuti dan pelacak jejak.

3) Metode amtsal atau perumpamaan: metode amtsal ini hampir sama dengan metode kisah

4) Metode uswah atau keteladanan

5) Metode pembiasaan: sesuatu yang disengaja dilakukan secara berulang-ulang agar sesuatu itu dapat menjadi kebiasaan.

6) Metode 'Ibrah dan Mau'idah: Ibrah berarti suatu kondisi psikis yang menyampaikan manusia kepada intisari sesuatu yang disaksikan, dihadapi dengan menggunakan nalar yang menyebabkan hati mengakuinya. Adapun kata mau'idhoh ialah nasehat yang lembut yang diterima oleh hati dengan cara menjelaskan pahala atau ancamanya.

7) Metode targhib dan tarhib atau janji dan ancaman.

\section{Konsep Pendidikan Akhlak Dalam Kitab"Tahdzīb Al-Akhläq Wa Tathhìr Al A'rāq" \\ a. Relevansi Tujuan Pendidikan Akhlak Ibn Miskawaih Dalam Kitab "Tahdzīb Al-Akblāq Wa Tathbìr Al-A'rāq"}

Menurut Miskawaih, pendidikan akhlak mempunyai pengertian memperbaiki perilaku manusia sesuai dengan derajat kemanusiaannya. Dengan demikian, tujuan utama pendidikan akhlak Ibnu Miskawaih adalah terbentuknya kepribadian yang luhur. Hal ini sesuai dengan pengertian pendidikan dipandang dari segi proses pembentukan pribadi yang dikemukakan oleh Umar Tirtarahardja, yaitu suatu kegiatan yang sistematis dan terarah bagi terbentuknya kepribadian peserta didik. Terkait dengan pengertian pendidikan, William Mc. Gucken, SJ juga menyatakan bahwa pendidikan adalah suatu perkembangan dan kelengkapan dari kemampuan manusia baik moral, intelektual ataupun jasmaniah yang terorganisir, dengan atau untuk kepentingan individual atau sosial dan diarahkan kepada kegiatan yang mengarah kepada Penciptanya sebagai tujuan akhirnya.

Dalam definisi ini terlihat jelas bahwa pendidikan harus mampu mengarahkan kemampuan yang terdapat pada diri manusia menjadi suatu kegiatan hidup yang berhubungan dengan Tuhannya, baik kegiatan itu bersifat individu atau sosial. Dengan demikian, arti pokok yang terkandung di dalam definisi tersebut adalah proses kependidikan mengarah ke tujuan tertentu.

Terbentuknya kepribadian yang luhur, di samping sebagai tujuan utama 
pendidikan Islam, juga berfungsi untuk membangun dan menjaga peradaban. W.L Dewarant, seorang ahli sejarah peradaban menyatakan bahwa faktor yang dapat membangun dan menjaga peradaban adalah akhlak. Apabila faktor ini hilang maka akan menyebabkan rapuhnya dasar peradaban.

Jika penulis telaah lebih lanjut tentang tujuan pendidikan menurut Ibn Miskawaih dan tujuan yang termuat dalam Pendidikan karakter bangsa maka nampak jelas adanya relevansi antara keduanya. Tujuan pendidikan menurut Ibn Miskawaih adalah tercapainya kemuliaan akhlak, terwujudnya pribadi susila, berwatak yang lahir daripadanya perilaku-perilaku luhur, atau katakanlah berbudi pekerti mulia. diperlukan adanya kesungguhan berusaha dan berlaku baik, seperti bersifat dermawan dan mempunyai banyak teman (santun).

Sementara itu tujuan Pendidikan Karakter Bangsa, pendidikan karakter bertujuan untuk menanamkan nilai dalam diri siswa dan sebagai pembaruan tata kehidupan bersama yang lebih menghargai kebebasan individu. Untuk tujuan jangka panjangnya adalah mendasarkan diri pada tanggapan aktif kontekstual individu atas impuls natural sosial yang diterimanya, yang pada gilirannya semakin mempertajam visi hidup yang akan diraih lewat proses pembentukan diri secara terus-menerus (on going formation), membentuk bangsa yang tangguh, kompetitif, berakhlak mulia, bermoral, bertoleran, bergotong royong, berjiwa patriotik, berkembang dinamis, berorientasi ilmu pengetahuan dan teknologi yang semua dijiwai oleh iman dan takwa kepada Tuhan Yang Maha Esa berdasarkan Pancasila. Sedangkan dari segi pendidikan, pendidikan karakter bertujuan untuk meningkatkan mutu penyelenggaraan dan hasil pendidikan yang mengarah pada pencapaian pembentukan karakter dan akhlak mulia peserta didik secara utuh, terpadu dan seimbang. Akhlak mulia inilah yang menjadi titik relevansi antara tujuan pendidikan menurut Ibn Miskawaih dan tujuan Pendidikan Karakter Bangsa.

\section{b. Relevansi Metode Pendidikan Akblak Ibn Miskawaih dalam Kitab "Tahdzīb Al-Akblāq Wa Tathbìr Al-A'rāq"}

Selanjutnya yang pertama metode yang dipakai Ibn Miskawaih yang diajukan Ibnu Miskawaih dalam mencapai akhlak yang baik, yang secara sederhana dapat digambarkan sebagai berikut: ${ }^{45}$ Pertama Adanya kemauan yang kuat untuk berlatih secara terus-menerus dan menahan diri (al-'Adat

${ }^{45}$ Ibn Miskawaih, Tahdzib al-Akhlaq wa Tathhir al-A'raq (Beirut: Mansyurat Dar Maktabah al-Hayat t.th), 151-153. 
wa al-Jihad) untuk memperoleh keutamaan dan sopan santun yang hakiki sesuai dengan keutamaan jiwa. watak seorang yang diperoleh dari kebiasaan/ latihan yang berulang-ulang, pada mulanya perilaku itu disertai kesengajaan atau pikiran kemudian berkelanjutan berulang-ulang hingga menjadi kebiasan/ watak. Latihan ini bertujuan agar manusia tidak mengikuti kemauan jiwa al-Syahwaniyat dan al-Ghadlabiyat. Kedua jiwa ini sangat terkait dengan alat tubuh, sehingga bentuk latihan dan menahan diri dapat dilakukan antara lain dengan tidak makan dan minum sesuatu yang merusak tubuh atau dengan melakukan puasa. Apabila kemalasan muncul maka latihan yang harus dilakukan antara lain adalah melakukan aktivitas yang berat, mengerjakan shalat dalam tempo yang lama atau melakukan pekerjaan baik yang mengandung unsur melelahkan. Metode semacam ini dinilai sebagai yang paling efektif untuk memperoleh keutamaan jiwa al-Syahwaniyat dan al-Ghadlabiyat. Kedua Menjadikan semua pengetahuan dan pengalaman orang lain sebagai cermin bagi dirinya. Maksud dari pengetahuan ini adalah pengetahuan tentang hukum akhlak yang berlaku yang memuat sebab munculnya kebaikan dan keburukan manusia. Dengan mengetahui hukum akhlak tersebut, seseorang tidak akan hanyut ke dalam perbuatan yang tidak terpuji karena bercermin dari kejelekan orang lain. Ketika ia melihat kejelekan atau kejahatan orang lain, ia intropeksi diri dan mencurigai bahwa dirinya, sedikit banyak, juga memiliki kekurangan seperti orang lain tersebut, kemudian ia menyelidiki dirinya. Metode semacam ini sebenarnya dapat dijadikan juga sebagai salah satu langkah mawas diri yang akan dibahas setelah ini. Dengan demikian, metode bercermin kepada orang lain mempunyai fungsi ganda, yakni sebagai metode untuk mencapai akhlak yang baik dan sebagai metode memperbaiki akhlak yang buruk. Namun agamalah yang dapat meluruskan anak-anak dan mereka dengan perilaku yang terpuji dan mempersiapkan mereka untuk menerima "hikmah", tanggung jawab orang tualah pelaksanaan pendidikan agama ini dengan berbagai upaya, kalau perlu mempergunakan ancaman hukuman sampai mereka terbiasa hidup bergama. ${ }^{46}$ Dan Ketiga Intropeksi diri/ mawas diri (muhasabat al-Nafs). Metode ini mengandung pengertian kesadaran seseorang untuk mencari pribadi secara sunguh-sungguh. Untuk menjelaskan maksud metode ini, Miskawaih mengutip pendapat Galen dari bukunya yang berjudul "Ta'aruf al-Mar 'Uyub Nafsib". Terdapat beberapa langkah yang dapat ditempuh dalam rangka mawas diri, yaitu: a. Berteman

${ }^{46}$ Ibid., 12. 
dengan orang tulus yang bersedia menunjukkan aib dirinya, b. Mengetahui aib pribadi melalui orang yang tidak menyukainya (musuhnya), c. Bercermin kepada perilaku orang lain.

Hal ini sesuai dengan konsep pendidikan yang ideal yang menyatakan bahwa pembiasaan tanpa disertai dengan pengetahuan yang cukup adalah kesalahan yang fatal. Kedua mempergunakan metode ancaman/hukuman sampai mereka terbiasa hidup bergama. Hal ini karena pembiasaan dan ancaman yang dilakukan secara terus-menerus akan menjadikan anak terbiasa berperilaku dengan nilai akhlak.

Metode ini sesuai dengan yang termaktub dalam Pendidikan Karakter Bangsa yang berbunyi pembiasaan adalah sesuatu yang disengaja dilakukan secara berulang-ulang agar sesuatu itu dapat menjadi kebiasaan. Kedua metode targhib dan tarbib atau janji dan ancaman. Metode ini bertujuan untuk mengokohkan iman dan akhlak atas dasar pengetahuan, agar orang yang dididik tetap di jalan yang benar dan tidak mudah terpengaruh dengan hal-hal yang negatif.

Metode ini juga sesuai yang termaktub dalam Pendidikan Karakter Bangsa, yaitu metode 'Ibrah dan Mau'idah: Ibrah berarti suatu kondisi psikis yang menyampaikan manusia kepada intisari sesuatu yang disaksikan, dihadapi dengan menggunakan nalar yang menyebabkan hati mengakuinya. Adapun kata mau'idhoh ialah nasehat yang lembut yang diterima oleh hati dengan cara menjelaskan pahala atau ancamanya.

\section{c Relevansi Materi Pendidikan Akblak Ibn Miskawaih dalam Kitab "Tahdzīb Al-Akblāq Wa Tathbir Al-A'rāq"}

Sementara itu untuk muatan isi kurikulumnya Ibn Miskawaih mengemukakan beberapa pelajaran yang harus dipelajari oleh seseorang murid yaitu pendidikan agama, bahasa, matematika dan sains. Miskawaih menyebutkan tiga hal yang dijadikan sebagai materi pendidikan akhlaknya, yaitu: Materi pendidikan terbagi menjadi 3 bagian. a. Pendidikan yang wajib bagi kebutuhan tubuh, b. Pendidikan yang wajib bagi kebutuhan jiwa, c. Pendidikan yang wajib terkait dengan hubungan manusia dengan sesamanya. Ketiga pokok materi ini dapat diperoleh dari berbagai jenis ilmu. Materi pendidikan akhlak yang wajib bagi keperluan jiwa dicontohkan dengan pembahasan tentang akidah yang benar, mengesakan Allah dengan segala kebesaran-Nya dan pemberian motivasi untuk senang kepada ilmu. Adapun materi yang terkait dengan keperluan manusia terhadap sesamanya dicontohkan dengan 
materi dalam ilmu múamalat, pertanian, perkawinan, saling menasehati, peperangan dan materi yang lain. ${ }^{47}$

Hal ini relevan dengan muatan kurikulum yang ada dalam Pendidikan Karakter Bangsa bahwa isi kurikulum juga harus berkenaan dengan pengetahuan ilmiah dan pengalaman belajar yang harus diberikan kepada siswa untuk mencapai tujuan pendidikan. Yang secara garis besar dibagi menjadi tiga kategori yaitu pengetahuan benar-salah (logika), pengetahuan baik buruk (etika), dan pengetahuan indah-jelek (estetika/seni).

Dari uraian diatas dapat penulis simpulkan bahwa antara konsep pendidikan Ibn Miskawaih dan konsep pendidikan karakter bangsa terdapat beberapa relevansi yaitu pada tujuan, metode, dan kurikulum.

\section{KESIMPULAN}

Konsep Pemikiran tentang pendidikan akhlak Ibnu Miskawaih yang tercermin dalam kitab Tahdzibul Akhlaq yang merupakan manifestasi pemikirannya. Pandangan Ibnu Miskawaih tentang pendidikan akhlaq berpijak pada konsep kejiwaan peserta didik. Pendidikan akhlaq menurutnya adalah suatu adalah keadaan jiwa yang mendorong timbulnya perbuatan secara spontan, tanpa membutuhkan pertimbangan dan pemikiran. Keadaan jiwa (akhlak) ini terbagi menjadi dua kategori, yaitu: Pembawaan sejak lahir (hereditas / alamiyah), dan akhlaq yang dihasilkan melalui proses latihan dan pembiasaan.

Konsep Pendidikan karakter pada esensinya adalah membentuk bangsa yang tangguh, kompetitif, berakhlak mulia, bermoral, bertoleran, bergotong royong, berjiwa patriotik, berkembang dinamis, berorientasi ilmu pengetahuan dan teknologi yang semua dijiwai oleh iman dan takwa kepada Tuhan Yang Maha Esa berdasa. Dengan kecerdasan emosi, seseorang akan dapat berhasil dalam menghadapi segala macam tantangan, termasuk tantangan untuk berhasil secara akademis.

Ibn Miskawaih dalam kitab Tahdzibul Akhlaq mengemukakan beberapa pelajaran yang harus dipelajari oleh seseorang murid yaitu pendidikan agama, bahasa, matematika dan sains. Hal ini relevan dengan muatan kurikulum yang ada dalam Pendidikan Karakter Bangsa bahwa isi kurikulum juga harus berkenaan dengan pengetahuan ilmiah dan pengalaman belajar yang harus diberikan kepada siswa untuk mencapai tujuan pendidikan.

${ }^{47}$ Ibn Miskawaih, Tahdzib al-Akblak wa Tathir al-A'raq. Terj. Helmi Hidayat, Menuju kesempurnaan akblak Islam (Jakarta: Mizan, 1999) 


\section{DAFTAR PUSTAKA}

Ahmad, Muhammad Abdul Qadir. Metodologi Pengajaran Agama Islam. Jakarta: Rineka Cipta, 2008.

Al-Ghazali. Ihya Ulum al-Din. Surabaya: Al- Hidayah, n.d.

Al-Ghazali, Imam. Ihya' Ulumiddin. Semarang: CV. Asy-Syifa, 1994.

Aminuddin. et. al. Membangun Karakter Dan Kepribadian Melalui Pendidikan Agama Islam. Yogyakarta: Graha Ilmu, 2007.

Anwar, Rosihan. Akblak Tasawuf. Bandung: Pustaka Setia, 2010.

Aunilah, Nurla Isna. Panduan Menerapkan Pendidikan Karakter di Sekolah. Jakarta: Laksana, 2011.

-. Panduan Menerapkan Pendidikan Karakter di Sekolah. Jakarta: Laksana, 2011.

Bafadhol, Ibrahim. "Pendiidkan Akhlak Perspektif Islam." Edukasi Islami: Jurnal Pendiidkan Islam 6, no. 2 (2017): 45-61.

Fahrudin, Irfan. Pilihan Sabda Rasul (Hadis-Hadis Pilihan). Jakarta: Bumi Aksara, 2001.

Forum Kajian Ilmiah (FKI) Lembaga Ittihadul Muballighin (LIM). Gerbang Pesantren: Pengantar Memahami Ajaran Ablussunnah wal Jamảah. Kediri: Bidang Penelitian dan Pengembangan LIM PP Lirboy, 2010.

Gunawan, Heri. Pendiidkan Karakter. Bandung: Alfabeta, 2012.

Hawwa, Said. Tazkiyatun Nafs intisari Ihya Ulumuddin. Jakarta: Pena Budi Aksara, 2005.

Herawati. "Pendidikan Akhlak Bagi Anak Usia DIni." Bunayya: Jurnal Pendidikan Anak III, no. 2 (Juli-Desember 2017).

http://etd.eprints.ums.ac.id/4829/. diakses 16 September 2012.

Ilyas, Yunahar. Kuliah Akblak. Yogyakarta: Lembaga Pengkajian dan Pengamalan Islam, 2006.

Jalaludin. Psikologi Agama. revisi. Jakarta: PT. Raja Grafindo Persada, 2005.

Kusuma Darma, et al. Pendidikan karakter. Bandung: PT. Remaja Rosda Karya, 2011.

Majid, Abdul. Pendidikan Karakter Perspektif Islam. Bandung: Remaja Rosda Karya, 2011. 
Miftahul Ulum, Basuki. Pengantar Ilmu Pendidikan Islam. Ponorogo: Stain Po Press, 2007.

Miskawaih, Abu ALi Ahmad Ibn Muhammad. Tahdzib al-Akblaq wa Tathhir al-A'raq. Beirut: Mansyurat Dar Maktabah al-Hayat., n.d.

Miskawaih, Ibn. "Menuju Kesempurnaan Akhlak Islam." In Tahdzib al-Akblak wa Tathir al-A'raq, translated by Helmi Hidayat. Jakarta: Mizan, 1999.

Muhammad, Alim. Pendidikan Agama Islam Upaya Pembentukan Pemikiran dan Kepribadian Muslim. Bandung: Remaja Rosda Karya, 2006.

Musfiroh, Tadkiroatun. "Pengembangan Karakter Anak Melalui Pendidikan Karakter." In Tinjauan Berbagai Aspek Character Building:Bagaimana Mendidik Anak Berkarakter, edited by Arismantoro. Yogyakarta: Tiara Wacana, 2008.

Muslich, Masnur. Pendidikan Karakter Menjawab Tantangan Krisis Multidimensional. Jakarta: Bumi Aksara, 2011.

Omeri, Nopan. "Pentingnya Karakter Dalam Dunia Pendidikan." MAPEN: Jurnal Manajer Pendidikan 9, no. 3 (2015).

Sholeh. "Pendidikan Akhlak dalam lingkungan Keluarga Menurut Imam Ghazali." Al- Thariqah: Jurnal Pendidikan Agama Islam 1, no. 1 (Juni 2016): 55-70.

UU No. 20 Tahun 2003 tentang. Sistem Pendidikan Nasional. Bandung: Umbara, 2003.

Wibowo, Agus. Pendidikan Karakter Strategi Membangun Karakter Bangsa Berperadaban. Yogyakarta: Pustaka Pelajar, 2012.

Yudi. Materi Pendidikan Agama Islam. Ponorogo: STAIN Po Press, 2009. 